JURNAL PENDIDIKAN, p-ISSN 2715-095X, e-ISSN 2686-5041

Volume 30, No.2, Juli 2021 (225-234)

Online: http://journal.univetbantara.ac.id/index.php/jp

\title{
Upaya Meningkatkan Kemampuan Guru Kelas Dalam Menerapkan Model-Model Pembelajaran Melalui Supervisi Kelas Di SD Negeri Pucangan 02 Kartasura Semester I Tahun Pelajaran 2019/2020
}

\author{
Tutik Nahari
}

SD Negeri Pucangan 02 Kecamatan Kartasura Kabupaten Sukoharjo,E-mail: tutiknahari02@gmail.com

Received: Mey 26, $2021 \quad$ Accepted: Juni 1, $2021 \quad$ Online Published: Juni 26, 2021

\begin{abstract}
Abstrak: Penelitian ini bertujuan untuk: (1) mendeskripsikan pelaksanaan kegiatan supervisi kelas guna meningkatkan kemampuan guru dalam menerapkan model-model pembelajaran; dan (2) meningkatkan kemampuan guru dalam menerapkan model-model pembelajaran di SD Negeri Pucangan 02 Kartasura, Kabupaten Sukoharjo melalui kegiatan supervisi kelas. Penelitian ini merupakan penelitian tindakan sekolah (PTS). Penelitian dilaksanakan pada semester 2 tahun pelajaran 2019/2020 dan semester 1 tahun pelajaran 2019/2020. Penelitian dilakukan selama 3 (enam) bulan, yaitu dimulai Agustus sampai Oktober 2019. Subjek dalam penelitian ini adalah 6 orang guru kelas, yaitu kelas I sampai VI. Penelitian ini menyimpulkan bahwa: (1) Langkah-langkah pelaksanaan kegiatan supervisi kelas guna meningkatkan kemampuan guru dalam menerapkan model-model pembelajaran dilakukan sebagai berikut: (a) Menganalisa kemampuan guru dalam mengelola kegiatan pembelajaran berdasarkan tipe pembelajaran terkini; (b) Mengupayakan supervisi kelas dengan cara memberikan bantuan pemikiran dan contoh-contoh yang tepat mengenai penggunaan model-model pembelajaran terkini yang konteks dengan keadaan sekolah; (c) Menetapkan jadwal kegiatan pengawsan kelas; (d) Menetapkan kriteria keberhasilan supervisi kelas agar dapat meningkatkan kemampuan guru dalam mengelola proses pembelajaran; e) Menyusun instrumen dan melaksanakan supervisi; dan (2) Kegiatan dalam mengawasi kelas dapat meningkatkan kemampuan guru dalam menerapkan model-model pembelajaran di SD Negeri Pucangan 02 Kartasura, Kabupaten Sukoharjo. Hal ini ditunjukkan dengan meningkatnya kemampuan guru dalam menerapkan model-model pembelajaran pada setiap siklus tindakan yang dilakukan. Akibat pemberian nilai terhadap kompetensi guru dalam menerapkan berbagai model pembelajaran mengalami peningkatan dari sebesar 71.78 pada tahap pra siklus tindakan, meningkat menjadi 80.11 pada tindakan masa I, kemudian meningkat menjadi 87.12 pada tindakan Siklus II.
\end{abstract}

Kata-kata Kunci: Kemampuan guru, model pembelajaran, kualitas pembelajaran, supervisi kelas.

\section{Efforts to Improve the Ability of Class Teachers in Implementing Learning Models through Class Supervision at SD Negeri Pucangan 02 Kartasura Semester I of the 2019/2020 Academic Year}

\section{Tutik Nahari}

SD Negeri Pucangan 02 Kecamatan Kartasura Kabupaten Sukoharjo,E-mail: tutiknahari02@gmail.com

\begin{abstract}
This study aims to: (1) describe the implementation of classroom supervision activities in order to improve the ability of teachers to apply learning models; and (2) increasing the ability of teachers to apply learning models at SD Negeri Pucangan 02 Kartasura, Sukoharjo Regency through classroom supervision activities. This research is a
\end{abstract}


school action research (PTS). The research was conducted in semester 2 of the 2019/2020 academic year and semester 1 of the 2019/2020 academic year. The research was conducted for 3 (six) months, starting from August to October 2019. The subjects in this study were 6 class teachers, namely grades I to VI. This study concludes that: (1) The steps for implementing classroom supervision activities in order to improve the ability of teachers to apply learning models are carried out as follows: (a) Identifying problems related to the ability of teachers to manage the learning process based on the latest learning models; (b) Establishing appropriate efforts when carrying out classroom supervision by providing thought assistance and appropriate examples of the use of current learning models in the context of school conditions; (c) Establish a schedule of classroom supervision activities; (d) Establish criteria for the success of classroom supervision in order to improve the ability of teachers to manage the learning process; e) Develop instruments and carry out supervision; and (2) Class supervision activities can improve the ability of teachers to apply learning models at SD Negeri Pucangan 02 Kartasura, Sukoharjo Regency. This is indicated by the increasing ability of teachers to apply learning models in each cycle of actions taken. The results of the assessment of the teacher's ability to apply learning models have increased from 71.78 in the pre-action cycle stage, increased to 80.11 in Cycle I action, then increased to 87.12 in Cycle II action.

Keywords: Teachers' abilities, learning models, quality of learning, classroom supervision.

\section{Pendahuluan}

Sekolah adalah suatu lembaga resmi yang berfungsi membantu orang tua dalam memberikan pendidikan kepada anak-anak mereka. Sekolah menyalurkan berbagai ilmu dan sikap kepada anak didiknya secara lengkap sesuai dengan yang mereka butuhkan. Manfaat sekolah tidak akan efektif apabila kumpulan dari beberapa komponen sistem sekolah tidak berjalan dengan baik, karena kelemahan dari salah satu komponen akan berpengaruh pada komponen yang lain yang pada akhirnya akan berpengaruh juga pada jalannya sistem itu sendiri. Guru merupakan salah satu dari bagian komponen sekolah.

Kenyataan bahwa sebagian besar siswa kurang mempersiapkan diri dalam belajar dan guru kurang memahami metode pembelajaran juga terjadi di SDN Pucangan 02 Kartasura, Kabupaten Sukoharjo. Hal ini terlihat dari munculnya berbagai kendala yang timbul dalam kegiatan belajar yang dilakukan. Beberapa kendala yang terjadi di sekolah tersebut selama ini antara lain meliputi: 1) Siswa mengalami kesulitan dalam memahami konsep; 2) Siswa pasif dalam proses pembelajaran; 3) Siswa belum terbiasa untuk bekerja sama dengan temannya dalam belajar; 4) Guru kurang mengaitkan materi pembelajaran dengan kehidupan sehari-hari; 5) Hasil belajar siswa pada kegiatan belajar rendah; 6) KKM tidak tercapai; 7) Kegiatan belajar tidak menarik bagi siswa; dan 8) Siswa terlihat tidak berminat dalam mengikuti proses pembelajaran.

Hasil pengamatan kasar tersebut mengindikasikan bahwa pembelajaran terlihat tidak efektif karena mengesampingkan aspek pembentukan karakter. Beberapa hal itu tentu saja menjadi suatu kendala bagi guru. Atas dasar hal tersebut, kepala sekolah perlu melakukan perbaikan untuk menjadikan hambatan tersebut menjadi sebuah kekuatan dalam pengelolaan kegiatan pembelajran yang efektif dan efisien sehingga nantinya akan mendapatkan hasil yang lebih baik.

Menurut Wajowasito dan Poerwadarminta (dalam Indrayanto, 2007:1), secara etimologis supervisi dialih bahasakan dari bahasa Inggris, yaitu "Supervision" artinya 
pengawasan. Sedangkan menurut Ametembun (dalam Indrayanto, 2007: 1), menyebutkan bahwa dilihat dari bentuk perkataannya, supervisi terdiri dari dua buah kata super + vision, yang artinya: Super $=$ atas, lebih, Vision $=$ lihat, tilik, awasi. Makna yang terkandung dari pengertian tersebut, bahwa seorang supervisor mempunyai kedudukan atau posisi lebih dari orang yang disupervisi, tugasnya adalah melihat, menilik atau mengawasi orang-orang yang disupervisi. Demikian pula para ahli dalam bidang administrasi pendidikan (dalam Indrayanto, 2007:1) memberikan kesepakatan bahwa supervisi pendidikan merupakan disiplin ilmu yang memfokuskan diri pada pengkajian peningkatan situasi belajar-mengajar.

Pembelajaran merupakan suatu istilah yang memiliki keterkaitan yang sangat erat dan tidak dapat dipisahkan satu sama lain dalam proses pendidikan. Pembelajaran seharusnya merupakan kegiatan yang dilakukan untuk menciptakan suasana atau memberikan pelayanan agar siswa belajar. Untuk itu, harus dipahami bagaimana siswa memperoleh pengetahuan dari kegiatan belajarnya. Jika guru dapat memahami proses pemerolehan pengetahuan, maka guru akan dapat menentukan strategi pembelajaran yang tepat bagi siswanya. Menurut Sudjana (2000) dalam Sugihartono, dkk (2007: 80) pembelajaran merupakan setiap upaya yang dilakukan dengan sengaja oleh pendidik yang dapat menyebabkan peserta didik melakukan kegiatan belajar. Dalam konteks pendidikan pengertian mutu, dalam hal ini mengacu pada proses pendidikan dan hasil pendidikan. Dalam "proses pendidikan" yang bermutu terlibat berbagai input, seperti; bahan ajar (kognitif, afektif, atau psikomotorik), metodologi (bervariasi sesuai kemampuan guru), sarana, dukungan administrasi dan sarana prasarana dan sumber daya lainnya serta penciptaan suasana yang kondusif (Hamdani, 2011: 193).

Rumusan masalah dalam penelitian ini adalah bagaimana pelaksanaan kegiatan supervisi kelas guna meningkatkan kompetensi guru dalam menerapkan berbagai model pembelajaran. Apakah kegiatan pengawasan kelas dapat meningkatkan kemampuan guru dalam menerapkan berbagai model pembelajaran di SDN Pucangan 02 Kecamatan Kartasura Kabupaten Kabupaten Sukoharjo. Sesuai dengan perumusan masalah tersebut di atas, maka tujuan penelitian ini adalah untuk mendeskripsikan pelaksanaan kegiatan supervisi kelas guna meningkatkan kemampuan guru dalam menerapkan modelmodel pembelajaran dan ntuk meningkatkan kemampuan guru dalam menerapkan modelmodel pembelajaran di SD Negeri Pucangan 02 Kartasura, Kabupaten Sukoharjo melalui kegiatan supervisi kelas.

\section{Metode Penelitian}

Sesuai dengan permasalahan dalam penelitian, maka penelitian dilakukan di SD Negeri Pucangan 02 Kartasura UPTD Pendidikan Kecamatan Kartasura Kabupaten Sukoharjo. Dipilihnya SD Negeri Pucangan 02 Kartasura UPTD Pendidikan Kecamatan Kartasura Kabupaten Sukoharjo sebagai tempat penelitian didasarkan pada adanya fakta bahwa kemampuan guru dalam penguasaan model-model pembelajaran di sekolah tersebut kurang optimal dan memerlukan peningkatan. Alasan lain yang mendasari adalah bahwa peneliti merupakan kepala sekolah di SD tersebut. Penelitian dilaksanakan pada semester I tahun pelajaran 2019/2020 Penelitian dillaksanakan selama 3 bulan yaitu bulan Agustus 2019 hingga bulan Oktober 2019. Prosedur tindakan penelitian didahului terlebih dahulu melakukan tindakan prasiklus dengan melaksanakan penilaian terhadap kegiatan belajar guru sebelum kegiatan supervisi dilaksanakan. 
Subyek penelitian ini adalah guru-guru kelas I sampai VI di SD Negeri Pucangan 02 Kecamatan Kartasura Kabupaten Sukoharjo yang terdiri dari 6 orang guru. Sedangkan objek penelitian berupa supervisi kelas guna meningkatkan kemampuan guru dalam pelaksanaan model-model dalam pembelajaran bagi guru kelas I sampai VI di SD Negeri Pucangan 02 Kecamatan Kartasura Kabupaten Sukoharjo.

Tabel 1. Data Subjek Penelitian

\begin{tabular}{cll}
\hline No. & Nama Guru & Kelas \\
1. & Siti Murthasiyah, A.Ma.Pd. & Guru Kelas I \\
2. & Firmansyah Kurniawan,S.Pd. & Guru Kelas II \\
3. & Intan Kurnia Jati,S.Pd. & Guru Kelas III \\
4. & Heny Sulistyawati, S. Pd. & Guru Kelas IV \\
5. & Nur'aini Tri Hastuti,S.|Pd. & Guru Kelas V \\
6. & Arisa Velly Ikawijayanti, S. Pd. & Guru Kelas VI \\
\hline
\end{tabular}

Rancangan metode penelitian ini adalah metode penelitian tindakan sekolah. Objek penelitian berupa supervisi kelas guna meningkatkan kemampuan guru dalam penguasaan model-model pembelajaran bagi guru kelas di SD Negeri Pucangan 02 Kecamatan Kartasura Kabupaten Sukoharjo. Sumber data dalam penelitian ini diperoleh dari berbagai sumber. Sumber-sumber data tersebut adalah data mengenai kemampuan guru dalam penguasaan model-model pembelajaran diperoleh dari guru kelas I sampai VI serta dari hasil pengamatan yang dilakukan oleh kepala sekolah dengan pengawas sekolah., data aktivitas siswa dalam pembelajaran diperoleh dari hasil pengamatan kepala sekolah selama melaksanakan supervisi kunjungan kelas, data penguasaan materi oleh siswa diperoleh dari hasil analisis dokumen nilai hasil belajar yang disusun guru kelas, data iklim pembelajaran diperoleh dari hasil wawancara dengan siswa di kelas I sampai VI yang dipilih secara acak.

Teknik pengumpulan data dalam penelitian ini menggunakan teknik observasi, wawancara dan dokumentasi. Teknik Observasi digunakan untuk menggali data dari sumber data yang berupa peristiwa, aktivitas, perilaku, tempat atau lokasi dan benda serta rekaman gambar (Sutopo, 2006: 75). Observasi dapat dilakukan secara langsung maupun tidak langsung. Menurut Spradley (dalam Sutopo, 2006: 75) dikatakan bahwa pelaksanaan teknik observasi dapat dibagi menjadi: 1) observasi tidak berperan, dan 2) observasi berperan.

Observasi dilakukan untuk mengamati kemampuan guru dalam penguasaan modelmodel pembelajaran, aktivitas siswa dalam proses pembelajaran, dan iklim kelas. Wawancara dilakukan dengan guru sebelum dan setelah kegiatan pembelajaran dilakukan. Wawancara dilakukan terhadap guru dan siswa. Studi dokumen dilakukan dengan penelitian mengenai dokumen-dokumen yang berkaitan dengan kemampuan guru dalam penguasaan model-model pembelajaran. Studi dokumen dilakukan untuk memperoleh data tentang kemampuan guru dalam perencanaan pembelajaran dan hasil belajar siswa.

\section{Hasil Penelitian}

Deskripsi kondisi awal kemampuan guru dalam penguasaan model-model pembelajaran pada guru kelas di SD Negeri Pucangan 02 Kartasura, Kabupaten Sukoharjo diperoleh dari hasil analisis dokumen, observasi, dan wawancara pada tahap pra siklus. 
Kemampuan guru dalam perencanaan, melaksanakan, mengevaluasi, dan menindaklanjuti hasil pembelajaran dalam mencapai kriteria ketuntasan minimal yang telah ditetapkan. Kemampuan guru dalam perencanaan, melaksanakan, mengevaluasi, dan menindaklanjuti hasil pembelajaran dalam mencapai kriteria ketuntasan minimal yang telah ditetapkan diukur berdasarkan 22 indikator. Penilaian diberikan dengan skor antara 1-4. Atas dasar hal tersebut maka skor yang diperoleh adalah antara 22-88. Skor selanjutnya dikonversi ke dalam bentuk nilai dengan menggunakan rumus:

$$
\frac{\sum X}{88} \times 100
$$

Hasil konversi nilai yang diperoleh kemudian diklasifikasi ke dalam 4 (empat) kategori, yaitu Amat Baik (A), Baik (B), Cukup Baik (C), dan Kurang Baik (D). Data hasil penilaian terhadap 6 orang guru kelas I sampai VI di SD Negeri Pucangan 02 Kartasura, Kabupaten Sukoharjo pada aspek perencanaan dan pelaksanaan pembelajaran tahap pra siklus tindakan dapat disajikan ke dalam tabel berikut ini.

Tabel 2

Hasil Penilaian Perencanaan dan Pelaksanaan Pembelajaran Tahap Pra Siklus

\begin{tabular}{|c|c|c|c|c|c|c|}
\hline \multirow{2}{*}{ No. } & \multirow{2}{*}{$\begin{array}{c}\text { Inisial } \\
\text { Guru }\end{array}$} & \multicolumn{2}{|c|}{ Aspek Penilaian } & \multirow{2}{*}{ Jumlah } & \multirow{2}{*}{ Nilai } & \multirow{2}{*}{ Keterangan } \\
\hline & & Perenc. & Pelaks & & & \\
\hline 1. & SM & 25.00 & 34.00 & 59.00 & 67.05 & $\mathrm{C}$ \\
\hline 2. & FK & 25.00 & 35.00 & 60.00 & 68.18 & $\mathrm{C}$ \\
\hline 3. & IKJ & 24.00 & 33.00 & 57.00 & 64.77 & $\mathrm{D}$ \\
\hline 4. & HS & 22.00 & 30.00 & 52.00 & 59.09 & $\mathrm{D}$ \\
\hline 5. & NTH & 31.00 & 42.00 & 73.00 & 82.95 & $\mathrm{~B}$ \\
\hline 6. & AVI & 25.00 & 34.00 & 59.00 & 88.64 & A \\
\hline & & & Jumlah & 379.00 & 430.68 & $C$ \\
\hline & Rata-rata & & & 63.17 & 71.78 & \\
\hline
\end{tabular}

Berdasarkan data pada tabel di atas, dapat diketahui bahwa nilai terendah yang diperoleh guru adalah 59.09 dan nilai tertinggi sebesar 88.64. Nilai rata-rata diperoleh sebesar 71.78. Mengingat nilai rata-rata berada pada kisaran antara $65.00-<75.00$, maka kemampuan guru dalam perencanaan dan pelaksanaan pembelajaran berada pada kategori cukup baik. Hasil pengamatan terhadap aktivitas belajar siswa pada tindakan Siklus I dapat disajikan ke dalam tabel berikut ini.

Tabel 3. Aktivitas Belajar Siswa pada Tindakan Siklus I

\begin{tabular}{llllll}
\hline \multirow{2}{*}{ No. } & Kelas & Aktif & \multicolumn{3}{c}{ Kurang Aktif } \\
1. & Kelas 1 & Jumlah & $\%$ & Jumlah & $\%$ \\
2. & Kelas 2 & 15 & $60.00 \%$ & 10 & $40.00 \%$ \\
3. & Kelas 3 & 16 & $59.26 \%$ & 11 & $40.74 \%$ \\
4. & Kelas 4 & 17 & $60.71 \%$ & 11 & $39.29 \%$ \\
5. & Kelas 5 & 21 & $70.00 \%$ & 9 & $30.00 \%$ \\
6. & Kelas 6 & 24 & $66.67 \%$ & 12 & $33.33 \%$ \\
& Jumlah & 26 & $68.42 \%$ & 12 & $31.58 \%$ \\
\hline
\end{tabular}

Penguasaan materi berupa ketuntasan belajar siswa dalam pembelajaran matematika pada tindakan Siklus I mengalami peningkatan dibandingkan kondisi sebelumnya. Hal ini 
ditunjukkan dengan meningkatnya tingkat ketuntasan belajar siswa dari sebesar $64.13 \%$ pada tahap pra siklus tindakan meningkat menjadi $72.83 \%$ pada tindakan Siklus I.

Tabel 4. Ketuntasan Belajar Siswa pada Tindakan Siklus I

\begin{tabular}{cccccc}
\hline \multirow{2}{*}{ No. } & \multirow{2}{*}{ Kelas } & \multicolumn{2}{c}{ Tuntas } & \multicolumn{2}{c}{ Belum Tuntas } \\
& & Jumlah & $\%$ & Jumlah & $\%$ \\
1. & Kelas III & 15 & $60.00 \%$ & 10 & $40.00 \%$ \\
2. & Kelas IV & 16 & $59.26 \%$ & 11 & $40.74 \%$ \\
3. & Kelas V & 17 & $60.71 \%$ & 11 & $39.29 \%$ \\
4. & Kelas VI & 21 & $70.00 \%$ & 9 & $30.00 \%$ \\
5. & Kelas I & 24 & $66.67 \%$ & 12 & $33.33 \%$ \\
6. & Kelas II & 26 & $68.42 \%$ & 12 & $31.58 \%$ \\
& Jumlah & 119 & $64.67 \%$ & 65 & $35.33 \%$ \\
\hline
\end{tabular}

Iklim pembelajaran diketahui dari hasil wawancara dengan siswa. Hasil wawancara menunjukkan bahwa situasi kegiatan belajar megajar yang dilakukan guru pada kegiatan Siklus I lebih baik dibandingkan dengan kondisi sebelumnya. Ringkasan hasil wawancara setelah dilaksanakan supervisi kelas tindakan Siklus I dapat disajikan sebagai berikut:

Tabel 5. Ringkasan Hasil Wawancara Tindakan Siklus I

\begin{tabular}{|c|c|c|}
\hline No. & Responden & Hasil Wawancara \\
\hline 1. & Siswa Kelas 1 & Pembelajaran berlangsung menjadi lebih bervariasi \\
\hline 2. & Siswa Kelas 2 & Siswa mulai memahami apa yang diajarkan guru \\
\hline 3. & Siswa Kelas 3 & $\begin{array}{l}\text { Guru sudah mulai menggunakan media dalam } \\
\text { pembelajaran yang dilaksanakan }\end{array}$ \\
\hline 4. & Siswa Kelas 4 & Siswa sudah mulai ada yang berani bertanya \\
\hline 5. & Siswa Kelas 5 & $\begin{array}{l}\text { Siswa mulai lebih siap dalam mengikuti proses } \\
\text { pembelajaran dengan membaca materi di rumah. }\end{array}$ \\
\hline 6. & Siswa Kelas 6 & Guru dalam menyampaikan materi lebih menarik \\
\hline
\end{tabular}

Berdasarkan hasil wawancara dengan beberapa orang siswa yang dipilih secara acak mengindikasikan bahwa kegiatan belajar mengajar yang dilakukan guru sudah mulai ada perbaikan. Pembelajaran sudah mulai bervariasi dan siswa sudah mulai termotivasi dalam mengikuti proses pembelajaran. Pembelajaran yang tadinya cenderung monoton dan lebih bersifat teacher-centered sudah mulai berubah dengan meningkatnya kegiatan siswa dalam pembelajaran. Data hasil penilaian terhadap 6 orang guru kelas I sampai VI di SD Negeri Pucangan 02 Kartasura, Kabupaten Sukoharjo pada aspek perencanaan dan pelaksanaan pembelajaran tindakan Siklus II dapat disajikan ke dalam tabel berikut ini.

Tabel 6. Hasil Penilaian Perencanaan dan Pelaksanaan Pembelajaran Tindakan Siklus II

\begin{tabular}{|c|c|c|c|c|c|c|}
\hline \multirow{2}{*}{ No. } & \multirow{2}{*}{$\begin{array}{l}\text { Inisial } \\
\text { Guru }\end{array}$} & \multicolumn{2}{|c|}{ Aspek Penilaian } & \multirow{2}{*}{ Jumlah } & \multirow{2}{*}{ Nilai } & \multirow{2}{*}{ Ket } \\
\hline & & Perenc. & Pelaks & & & \\
\hline 1. & SM & 33.00 & 46.00 & 79.00 & 89.77 & B \\
\hline 2. & FK & 31.00 & 43.00 & 74.00 & 84.09 & B \\
\hline 3. & IKJ & 31.00 & 41.00 & 72.00 & 81.82 & $\mathrm{C}$ \\
\hline
\end{tabular}




\begin{tabular}{|c|c|c|c|c|c|c|}
\hline 4. & HS & 28.00 & 37.00 & 65.00 & 73.86 & $\mathrm{D}$ \\
\hline 5. & NTH & 36.00 & 48.00 & 84.00 & 95.45 & A \\
\hline \multirow[t]{3}{*}{6.} & AVI & 36.00 & 50.00 & 86.00 & 97.73 & A \\
\hline & \multicolumn{3}{|c|}{ Jumlah } & 460.00 & 522.73 & $\Delta$ \\
\hline & \multicolumn{3}{|c|}{ Rata-rata } & 76.67 & 87.12 & A \\
\hline
\end{tabular}

Nilai kemampuan guru dalam perencanaan dan pelaksanaan pembelajaran selanjutnya diklasifikasikan ke dalam 4 kategori. Berdasarkan sajian data pada tabel di atas, dapat diketahui bahwa jumlah guru dengan kemampuan perencanaan dan pelaksanaan pembelajaran kategori Amat Baik (A) adalah sebanyak 3 orang guru atau 50.00\%. Jumlah guru dengan kemampuan perencanaan dan pelaksanaan pembelajaran kategori Baik (B) adalah sebanyak 2 orang guru atau 33.33\%. Jumlah guru dengan kemampuan perencanaan dan pelaksanaan pembelajaran kategori Cukup Baik (C) adalah sebanyak 1 orang guru atau 16.67\%. Jumlah guru dengan kemampuan perencanaan dan pelaksanaan pembelajaran kategori Kurang Baik (D) tidak ada. Data kemampuan guru dalam perencanaan dan pelaksanaan pembelajaran berdasarkan kategori pada tindakan Siklus II selanjutnya dapat disajikan ke dalam tabel berikut.

Tabel 7. Klasifikasi Kemampuan Guru dalam Perencanaan dan Pelaksanaan Pembelajaran Tindakan Siklus II

\begin{tabular}{llll}
\hline No. & Klasifikasi & Jumlah & $\%$ \\
1. & Amat Baik & 3 & $50.00 \%$ \\
2. & Baik & 2 & $33.33 \%$ \\
3. & Cukup Baik & 1 & $16.67 \%$ \\
4. & Kurang Baik & & $0.00 \%$ \\
& Jumlah & 6 & $100.00 \%$ \\
\hline
\end{tabular}

Aktivitas siswa dalam pembelajaran setelah dilaksanakan kegiatan supervisi tindakan Siklus II diketahui dari hasil pengamatan kasar terhadap aktivitas siswa selama berlangsungnya proses pembelajaran matematika. Hasil pengamatan mengindikasikan bahwa aktivitas siswa mengalami peningkatan dibandingkan dengan kondisi sebelumnya. Hal ini diindikasikan dengan meningkatnya prosentase tingkat aktivitas siswa dalam pembelajaran, yaitu dari sebesar $64.67 \%$ pada tindakan Siklus I, meningkat menjadi $78.26 \%$ pada tindakan Siklus II. Hasil pengamatan terhadap aktivitas belajar siswa pada tindakan Siklus II dapat disajikan ke dalam tabel berikut ini.

Tabel 8. Aktivitas Belajar Siswa pada Tindakan Siklus II

\begin{tabular}{llllll}
\hline \multirow{2}{*}{ No. } & \multirow{2}{*}{ Kelas } & Aktif & \multicolumn{3}{c}{ Kurang Aktif } \\
1. & Kelas 1 & Jumlah & $\%$ & Jumlah & $\%$ \\
2. & Kelas 2 & 19 & $76.00 \%$ & 6 & $24.00 \%$ \\
3. & Kelas 3 & 21 & $77.78 \%$ & 6 & $22.22 \%$ \\
4. & Kelas 4 & 21 & $75.00 \%$ & 7 & $25.00 \%$ \\
5. & Kelas 5 & 24 & $80.00 \%$ & 6 & $20.00 \%$ \\
6. & Kelas 6 & 31 & $77.78 \%$ & 8 & $22.22 \%$ \\
& Jumlah & 144 & $78.26 \%$ & 40 & $18.42 \%$ \\
\hline
\end{tabular}




\section{Pembahasan}

Kemampuan guru dalam menerapkan model-model pembelajaran pada tahap pra siklus tindakan masih belum optimal. Hal ini diindikasikan dengan nilai rata-rata kemampuan guru yang baru mencapai 71.78 atau berada pada rentang kategori Cukup Baik (C). Kondisi tersebut pada gilirannya dapat mempengaruhi tingkat aktivitas siswa dalam pembelajaran, penguasaan siswa terhadap materi pembelajaran, dan iklim pembelajaran. Atas dasar hal tersebut, kepala sekolah perlu melakukan perbaikan dengan melaksanakan kegiatan supervisi kelas. Kegiatan supervisi kelas yang dilakukan dengan tujuan meningkatkan kemampuan guru dalam menerapkan model-model pembelajaran cukup efektif. Hal ini ditunjukkan dengan meningkatnya nilai rata-rata kemampuan guru dari sebesar 71.78 pada tahap pra siklus tindakan, meningkat menjadi 80.11 pada tindakan Siklus I, kemudian meningkat menjadi 87.12 pada tindakan Siklus II. Peningkatan kemampuan guru dalam menerapkan model-model pembelajaran dari tahap pra siklus tindakan hingga tindakan Siklus II dapat diringkaskan ke dalam tabel berikut ini.

Tabel 9. Peningkatan Kemampuan Guru dalam Menerapkan Model-model Pembelajaran

\begin{tabular}{ccccccccccc}
\hline & Inisial & \multicolumn{3}{c}{ Pra Siklus } & \multicolumn{3}{c}{ Siklus I } & \multicolumn{3}{c}{ Siklus II } \\
No. & Guru & Skor & Nilai & Ket. & Skor & Nilai & Ket. & Skor & Nilai & Ket. \\
1. & SM & 59.00 & 67.05 & C & 70.00 & 79.55 & B & 79.00 & 89.77 & A \\
2. & FK & 60.00 & 68.18 & C & 69.00 & 78.41 & B & 74.00 & 84.09 & B \\
3. & IKJ & 57.00 & 64.77 & D & 65.00 & 73.86 & C & 72.00 & 81.82 & B \\
4. & HS & 52.00 & 59.09 & D & 57.00 & 64.77 & D & 65.00 & 73.86 & C \\
5. & NTH & 73.00 & 82.95 & B & 80.00 & 90.91 & A & 84.00 & 95.45 & A \\
6. AVI & 78.00 & 88.64 & A & 82.00 & 93.18 & A & 86.00 & 97.73 & A \\
Jumlah & 379.0 & 430.7 & & 423.0 & 480.7 & & 460.0 & 522.7 & \\
Rata-rata & 63.17 & 71.78 & & 70.50 & 80.11 & & 76.67 & 87.12 & A \\
Tertinggi & 78.00 & 88.64 & C & 82.00 & 93.18 & B & 86.00 & 97.73 & \\
\multicolumn{2}{l}{ Terendah } & 52.00 & 59.09 & & 57.00 & 64.77 & & 65.00 & 73.86 & \\
\hline
\end{tabular}

Hasil-hasil tersebut di atas menunjukkan bahwa peningkatan kemampuan guru dalam penguasaan model-model pembelajaran diindikasikan dengan meningkatnya jumlah guru yang memiliki kemampuan dengan kategori Amat Baik (A) dan Baik (B) pada setiap siklus tindakan.

Tabel 10. Peningkatan Kemampuan Guru dalam Menerapkan Model-model Pembelajaran

\begin{tabular}{clcccccc}
\hline \multirow{2}{*}{ No. } & Klasifikasi & \multicolumn{2}{c}{ Tahap Pra-siklus } & \multicolumn{2}{c}{ Siklus I } & \multicolumn{2}{c}{ Siklus II } \\
1. & Amat Baik & 1 & $16.67 \%$ & 2 & $33.33 \%$ & 3 & $50.00 \%$ \\
2. & Baik & 1 & $16.67 \%$ & 2 & $33.33 \%$ & 2 & $33.33 \%$ \\
3. & Cukup Baik & 2 & $33.33 \%$ & 1 & $16.67 \%$ & 1 & $16.67 \%$ \\
4. & Kurang Baik & 2 & $33.33 \%$ & 1 & $16.67 \%$ & 0 & $0.00 \%$ \\
& Jumlah & 6 & $100.00 \%$ & 6 & $100.00 \%$ & 6 & $100.00 \%$ \\
\hline
\end{tabular}


Peningkatan kemampuan guru dalam penguasaan model-model pembelajaran berdasarkan kategori dari tahap pra siklus hingga tindakan Siklus II dapat disajikan ke dalam diagram berikut ini.

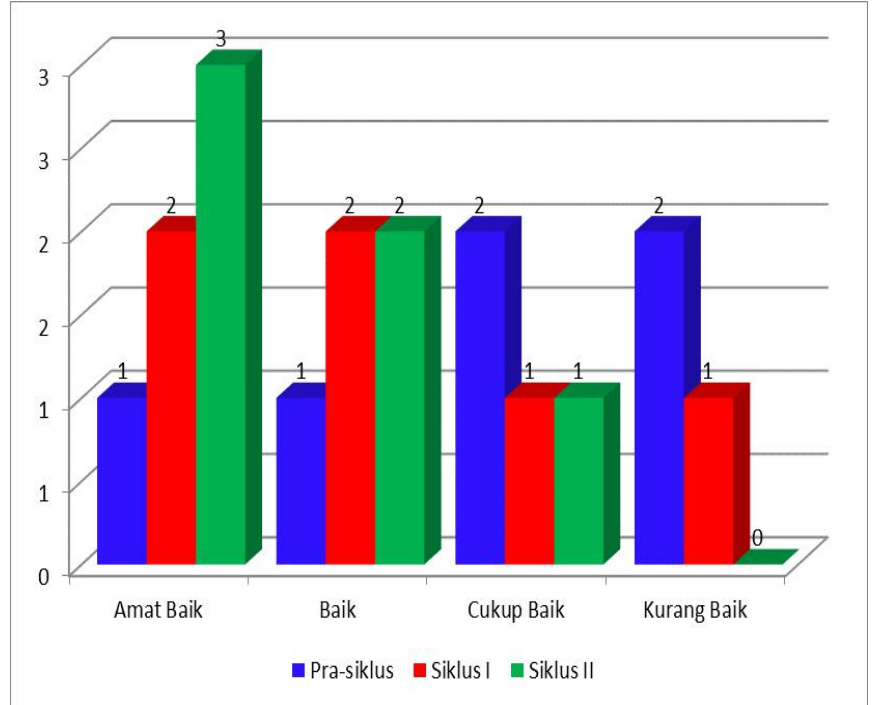

Gambar 1. Diagram Peningkatan Kemampuan Guru dalam Menerapkan Model Pembelajaran

\section{Simpulan dan Saran}

Kegiatan supervisi kelas dapat meningkatkan kemampuan guru dalam menerapkan model-model pembelajaran di SD Negeri Pucangan 02 Kartasura, Kabupaten Sukoharjo. Hal ini ditunjukkan dengan meningkatnya kemampuan guru dalam menerapkan modelmodel pembelajaran pada setiap siklus tindakan yang dilakukan. Hasil penilaian terhadap kemampuan guru dalam menerapkan model-model pembelajaran mengalami peningkatan dari sebesar 71.78 pada tahap pra siklus tindakan, meningkat menjadi 80.11 pada tindakan Siklus I, kemudian meningkat menjadi 87.12 pada tindakan Siklus II.

Motivasi yang sudah tertanam khususnya dalam penyusunan RPP penerapan modelmodel pembelajaran hendaknya terus dipertahankan dan ditingkatkan/ dikembangkan. RPP penerapan model-model pembelajaran yang disusun/ dibuat hendaknya mengandung komponen-komponen RPP penerapan model-model pembelajaran secara lengkap dan baik karena RPP penerapan model-model pembelajaran merupakan acuan/pedoman dalam melaksanakan pembelajaran. Dokumen RPP penerapan model-model pembelajaran hendaknya dibuat minimal rangkap, satu untuk arsip sekolah dan satunya lagi untuk pegangan guru dalam melaksanakan proses pembelajaran.

\section{Daftar Rujukan}

Ahmad. (2020). Peningkatan Kompetensi Pedagogik Guru Dalam Pembelajaran Jarak Jauh Melalui Pendampingan Sistem Daring, Luring, atau Kombinasi Pada Masa New Normal Covid-19, Jurnal Paedagogy volume7(2), Oktober. 
Atik Sholihatul, Hikmawati. (2020). Efektivitas Model Pembelajaran Daring Dalam Perkuliahan Bahasa Arab Di Institut Agama Islam Sunan Kalijogo Malang, Jurnal Muhadasah: Jurnal Pendidikan Bahasa Arab, volume 2(1), Juni.

Asmuni, (2020). Problematika Pembelajaran Daring di Masa Pandemi Covid-19 dan Solusi Pemecahannya, Jurnal Paedagogy: Jurnal Penelitian dan Pengembangan Pendidikan volume 7(4), Oktober.

Ekantini, Anita. (2020). EfektivitasPembelajaran Daring pada Mata Pelajaran IPA di Masa Pandemi Covid-19: Studi Komparasi Pembelajaran Luring dan Daring pada Mata Pelajaran IPA SMP, Jurnal Pendidikan Madrasah, volume 5(2), November.

Erwan Rio, Pratama dan Sri Mulyati. (2020). Pembelajaran Daring dan Luring Pada Masa Pandemi Covid-19, JurnalGagasan Pendidikan Indonesia, volume 1(2), Desember.

Iim Waliman, dkk. 2001. Supervisi kelas (Modul Manajemen Berbasis Sekolah). Bandung : DinasPendidikan Provinsi Jawa Barat.

Marsh, Collin. 1996. Handbook for beginning teachers. Sydney : Addison Wesley Longman Australia Pry Limited.

Peraturan Pemerintah Nomor 19 tahun 2005 tentang Standar Nasional Pendidikan.

Peraturan Pemerintah Nomor 22 tahun 2006 tentang Standar Isi untuk Satuan Pendidikan Dasar dan Menengah.

Sahertian, Piet, A. dan Frans Mataheru. 2001. Prinsip Teknik Supervisi Pendidikan. Surabaya: UsahaNasional.

Sardiman, A. M. 2004. Interaksi dan motivasi belajar-mengajar. Jakarta: Rajawali

Sudrajat, Akhmad. 2010. "Pendekatan Pembelajaran". Artikel., http://www.akhmad_sudrajat.bogspot.com

Suherman, Erman. 2009. Model-model Pembelajaran. http ://researchengines.com/1207trimo1. html Penelitian Tindakan Sekolah.

Sukmadinata, Nana Syaodih. 2006. Pengendalian Mutu Pendidikan Sekolah Menengah (Konsep, prinsip, dan instrumen). Bandung : Aditama.

Undang-undang Republik Indonesia Nomor 20 Tahun 2003 tentang Sistem Pendidikan Nasional.

Winataputra, Udin . 2004. Model pembelajaran. Jakarta: Rineka Cipta.

Wiriaatmadja, Rochiati. 2006. Metode Penelitian Tindakan Kelas. Bandung: PT Remaja Rosdakarya. 